\title{
A COMPARATIVE ANALYSIS OF PERCEIVED SERVICE QUALITY AND PATIENT SATISFACTION BETWEEN MUHAMMADIYAH GAMPING AND YOGYAKARTA HOSPITALS
}

\author{
Ahmad Aulia Ghufron, Susanto \\ Masters Program in Hospital Management, Universitas \\ Muhammadiyah Yogyakarta
}

\begin{abstract}
Background: Fast growth of hospitals has resulted in intense competition, which demands competitive patient products and trust. Quality services become the key of survival. Muhammadiyah Yogyakarta and Gamping Hospital are private referal hospitals that collaborate with the managing body of the national health insurance (BPJS). Each hospital is expected to deliver quality and satisfactory health services. Hospitals that fail to satisfy customers will face problem due to bad reputation. This study aimed to compare perceived service quality and patient satisfaction between Muhammadiyah Gamping and Yogyakarta Hospitals.

Subjects and Method: This was a cross sectional study conducted in hemodialysis unit at Muhammadiyah Gamping and Yogyakarta hospitals, Yogyakarta, in February 2018. A sample of 160 patients who were enrolled in national health insurance (JKN) was selected for this study, consisting 80 patients in Muhammadiyah Gamping hospital and 80 patients in Muhammadiyah Yogyakarta hospitals. The dependent variables were perceived quality of health service and patient satisfation. The perceived quality of health service was measured by SERVQUAL comprising 5 dimensions: reliability, tangible, assurance, responsiveness, and empathy. The independent variable was hospital (Muhammadiyah Gamping versus Yogyakarta). The data were collected by questionnaire. Difference in means between two hospitals were tested by t-test. Difference in percents between two hospitals were tested by chi square.

Results: Percent of patients satisfied was lower in Gamping $(55,68.8 \%)$ than that in Yogyakarta $(72,90.0 \%)$ and it was statistically significant. However, scores in tangible and responsiveness dimensions were higher in Gamping than Yogyakarta. Scores in reliability, assurances, and empathy, were comparable between Gamping and Yogyakarta.
\end{abstract}

Conclusion: Percent of patients satisfied is lower in Gamping than in Yogyakarta.

Keywords: satisfaction, national health insurance, hospital, patients

\section{Correspondence:}

Ahmad Aulia Ghufron. Masters Program in Hospital Management, Universitas Muhammadiyah Yogyakarta, Jl. Lingkar Selatan, Tamantirto, Kasihan, Bantul, Yogyakarta, Email: alghufron7891@yahoo.com. Mobile: 085714887891 